\title{
KONTRIBUSI SIKAP SOSIAL, STATUS SOSIAL EKONOMI DAN KONSEP DIRI TERHADAP HASIL BELAJAR SISWA KELAS V SD DI GUGUS III KECAMATAN KERAMBITAN TABANAN
}

\author{
D.G. Suryawati ${ }^{1}$ I.W. Lasmawan ${ }^{2}$, I.M. Ardana ${ }^{3}$ \\ ${ }^{123}$ Program Studi Pendidikan Dasar \\ Universitas Pendidikan Ganesha \\ Singaraja, Indonesia

\begin{abstract}
e-mail: desakgedesuryawati79@gmail.com ${ }^{1}$, wayan.lasmawan@undiksha.ac.id ${ }^{2}$, ardanaimade@yahoo.com ${ }^{3}$
\end{abstract}

\begin{abstract}
Abstrak
Penelitian ini bertujuan untuk mengetahui kontribusi sikap sosial, status sosial ekonomi dan konsep diri terhadap hasil belajar siswa kelas V SD di gugus III Kecamatan Kerambitan Tabanan. Penelitian ini menggunakan pendekatan expost-facto. Populasi yang diambil sejumlah 87 siswa yang semuanya merupakan siswa kelas lima di sekolah tersebut. Sementara sampel yang digunakan adalah semua dari jumlah populasi tersebut karena populasi yang diambil tidak terlalu banyak. Metode pengumpulan data yang digunakan pada penelitian ini adalah kuesioner dan studi dokumentasi. Data sikap sosial, status sosial ekonomi dan konsep diri dikumpulkan dengan kuesioner, sementara data terkait hasil capaian belajar siswa diambil dari nilai ujian pertengahan semester. Untuk analisa datanya dilakukan dengan hubungan parsial, regresi ganda dan sedehana. Sehingga kesimpulan yang didapatkan, yaitu: 1) Adanya kesignifikansi kontribusi antara hasil belajar siswa dan sikap sosial sebesar $57,9 \%$ dan kefektifan sambungan sebesar $36,29 \%$, 2) Adanya kesignifikansi kontribusi antara hasil belajar siswa dan status sosial ekonomi sebesar $48 \%$ dan kefektifan sambungan sebesar $14,99 \%, 3)$ Adanya kesignifikansi kontribusi antara hasil belajar siswa dan konsep diri sebesar $45,3 \%$ dan kefektifan sambungan sebesar 22,50\%, dan 4) Gabungan dari ketiga variabel tersebut, Adanya kesignifikansi kontribusi antara hasil belajar siswa dengan sikap sosial, status sosial ekonomi, dan konsep diri sebesar $73,8 \%$.
\end{abstract}

Kata Kunci : Hasil Belajar; Konsep Diri; Sikap Sosial; Status Sosial Ekonomi

\begin{abstract}
This study aims to determine the contribution of social attitudes, socio-economic status and self-concept to the learning outcomes of fifth grade elementary school students in cluster III, Kerambitan District, Tabanan. This study uses an ex post-facto approach. The population in this study were all students of Class V SD in cluster III, Kerambitan District, Tabanan, totaling 87 students. Because the population in this study was not too large, the entire population in this study was directly used as the research sample. The data collection methods used in this study were questionnaires and documentation studies. Data on social attitudes, socioeconomic status and self-concept were collected by means of a questionnaire, while data on student learning outcomes used students' midterm test scores. The data analysis used in this study is simple regression, multiple regression, and partial correlation. Based on the research that has been done, it is concluded that: 1) there is a significant contribution of social attitudes to the learning outcomes of fifth grade elementary school students in cluster III, Kerambitan District, Tabanan. The contribution of social attitudes to student learning outcomes was $57.9 \%$ with an effective contribution of $36.29 \%$,2) there was a significant contribution of socioeconomic status to the learning outcomes of grade V SD students in cluster III, Kerambitan District, Tabanan. The contribution of socioeconomic status to student learning outcomes is $48 \%$ with an effective contribution of $14.99 \%, 3$ ) there is a significant contribution of self-concept to the learning outcomes of grade V SD students in cluster III, Kerambitan District, Tabanan. The contribution of selfconcept to student learning outcomes is $45.3 \%$ with an effective contribution of $22.50 \%$, and 4 ) collectively, there is a significant contribution of social attitudes, socioeconomic status, and selfconcept to learning outcomes of fifth grade elementary school students. in cluster III, Kerambitan District, Tabanan. The contribution of social attitudes, socioeconomic status, and self-concept to student learning outcomes was $73.8 \%$.
\end{abstract}


Keywords : Learning Outcomes; Self-Concept; Social Attitudes; Socioeconomic Status

\section{PENDAHULUAN}

Sekolah Dasar Negeri 2 Batuaji Kerambitan Tabanan merupakan sekolah dasar yang terletak di pedesaan. Proses pembelajaran yang terjadi pun terlihat kurang inovatif. Dalam proses belajar mengajar di kelas para peserta didik terlihat kurang di dalam memperhatikan dan mendengarkan penjelasan dari guru. Selain itu ada beberapa peserta didik yang sebenarnya belum memahami materi pembelajaran, namun tidak mau bertanya dengan guru. Hal ini membuat hasil belajar siswa cenderung kurang maksimal.

Selain pembelajaran yang dilakukan guru, penyebab lain yang diprediksi memberikan pengaruh terhadap capaian belajar peserta didik adalah sikap sosial peserta didik. Sikap atau perilaku yang ditunjukkan ketika berhadapan dengan orang lain dikatakan dengan sikap sosial. Setiap perilaku sosial berkaitan dengan kekonsitenan seseorang dalam merespon hal-hal di luar dirinya (Herawati dalam Dimyati \& Mudjiono, 2013). Semakin baik sikap sosial siswa tentunya siswa merasa percaya diri dalam kegiatan pembelajaran. Rasa percaya diri ini akan membuat siswa berani di dalam memcehakan sebuah permasalahan ketika belajar.

Letak gugus sekolah yang cenderung berada di pedesaan tentunya sebagian besar siswanya berasal dari wilayah pedesaan. $\mathrm{Hal}$ ini cenderung mempengaruhi sikap sosial siswa. Sikap siswa di sekolah terlihat malu-malu dalam bergaul dengan teman yang belum akrab dikenalnya, selain itu dalam pembelajaran siswa terlihat kurang aktif dalam belajar. Permasalahan lain yang juga terjadi adalah adanya beberapa siswa yang sering berkelahi di sekolah. Hal ini mengindikasikan sikap sosial siswa di sekolah perlu diberikan perhatian oleh guru maupun pihak sekolah.

Selain sikap sosial, penyebab lainnya yang juga diprediksi memberikan pengaruh terhadap capain belajar peserta didik ialah status sosial ekonomi dari keluarganya. Usman (2004:126) mengatakan bahwa status sosial ekonomi merupakan seperangkat kewajiban dan haknya di dalam berinteraksi dengan masyarakat yang Nampak dalam kepemilikan status ekeonomi dan, kekuasaan dan kekayaan ekonomi. Dimyati (1990: 99) menjelaskan bahwa status sosial ekonomi mencakup fasilitas, jabatan, penghasilan, pekerjaan dan pendidikan orang tua.

Menurut Nasution (1994:73) bahwa status atau kedudukan merupakan penentu atas posisi seseorang pada sebuah sturuktur masyarakat yang mengindikasikan dari golongan mana ia berasal, apakah golongan atas atau bawah. Dengan hal ini menjadikan perannya di dalam masyarakat berbeda. Peran seseoang di masyarkat berbeda karena pada dasarnya setiap orang memiliki karakteristik yang berbeda dengan lainnya meskipun statusnya sama.

Keadaan status sosial ekonomi siswa kelas V SD di gugus III Kecamatan Kerambitan Tabanan sangat beragam. Hal ini dikarenakan orang tua siswa berasal dari berbagai kalangan/profesi pekerjaan. Misalnya: petani, buruh serabutan, wira swasta, pegawai swasta, dan pegawai negeri sipil. Perbedaan status sosial ekonomi siswa ini terlihat sangat heterogen. Hal ini juga berimplikasi pada fasilitas pembelajaran yang didapatkan siswa di rumahnya. Untuk peserta didik yang ekonominya tergolong mampu, anaknya cenderung diberikan kesempatan untuk mengikuti les di berbagai tempat. Selain itu, anaknya juga sudah diberikan smart phone, sehingga dalam mengakses informasi tentang pembelajaran cukup mudah, karena siswa dapat mengakses di internet. Namun berbeda halnya dengan peserta didik yang ekoniminya tergolong kurang mampu. Siswa yang berasal dari ekonomi kurang mampu cenderung kurang mendapatkan perhatian yang serius dari orang tua tentang pendidikan anaknya. Lebih sering terlihat orang tua setelah anaknya pulang sekolah mengajak anaknya untuk membantu bekerja membantu orangtuanya. Hal seperti ini tentunya membuat waktu belajar siswa di 
rumah menjadi terbatas, dan siswa pun cenderung hanya mendapatkan pembelajaran lewat sekolah saja. Hal ini tentunya sangat berdampak pada pencapaian belajar peserta didik di sekolah.

Penyebab lainnya yang juga diprediksi memberikan pengaruh bagi capaian belajar peserta didik di sekolah, yakni konsep diri siswa. Spencer and Spencer (dalam Uno, 2011:79) menyatakan bahwa konsep diri merupakan harga, nilai dan sikap diri seorang individu. Konsep diri bisa memengaruhi pandangan seseorang terhadap sosialnya. Peserta didik yang mempunyai konsep diri yang baik cenderung adaptif, kooperatif, dan normatif. Peserta didik yang memounyai konsep diri yang baik akan mampu menyelesaikan masalah, independen, optimis dan memiliki karakteristik yang terbebas dari rasa gelisah, cemas, takut yang berlebihan dan rasa kesepian.

Berdasarkan observasi yang dilakukan di kelas V SD di gugus III Kecamatan Kerambitan Tabanan terlihat bahwa konsep diri siswa cenderung rendah. Demikian ini disebabkan kurangnya optimistis dalam diri peserta didik di dalam melakukan sesuatu. Terutama pada saat siswa diajak mengikuti lomba-lomba di luar sekolah. Siswa terlihat agak minder dikarenakan merasa berasal dari desa. Padahal belum tentu kemampuan mereka kalah dengan anak-anak yang berasal atau bersekolah di kota. Selain itu dalam proses pembelajaran siswa pun kurang berani dalam berargumentasi hanya cenderung menerima apa yang dikatakan guru saja. Apabila siswa diberikan permasalahan dalam proses pembelajaran yang harus dipecahkannya, siswa terlihat agak takut untuk mencoba sesuatu yang baru. Padahal kalau siswa mau mencoba pasti bias mengerjakan/menyelesaikan permasalahan tersebut.

Permasalahan-permasalahan yang berkaitan dengan tiga variabel di atas yakni: sikap sosial, status sosial ekonomi, dan konsep diri siswa selama ini cenderung sangat jarang diperhatikan oleh guru. Bahkan guru cenderung menganggap permasalahan itu merupakan permasalahan yang biasa dan tidak perlu ditindak lajuti, padahal permasalahan ini diprediksi mempengaruhi pencapaian belajar peserta didik di sekolah.

Ukuran kontribusi dari sikap sosial, status sosial ekonomi dan konsep diri terhadap hasil belajar siswa kelas V SD di gugus III Kecamatan Kerambitan Tabanan belum diketahui secara pasti. Hal itu dikarenakan selama ini belum ada penelitian yang meneliti tentang variabel tersebut di gugus III Kecamatan Kerambitan Tabanan. Padahal hal itu sangat penting mengingat pencapaian belajar peserta didik di sekolah tersebut belum tercapai secara maksimal. Dengan sebab itu peneliti melakukan research dengan judul kontribusi sikap sosial, status sosial ekonomi dan konsep diri terhadap hasil belajar siswa kelas V SD di gugus III Kecamatan Kerambitan Tabanan.

Tujuan dari diadakannya penelitian ini ialah sebagai berikut.

1) Untuk mengetahui seberapa besar kontribusi sikap sosial atas capaian belajar peserta didik kelas V SD di gugus III Kecamatan Kerambitan Tabanan.

2) Untuk mengetahui seberapa besar kontribusi status sosial ekonomi atas capaian belajar peserta didik kelas lima SD di sekolah tersebut.

3) Untuk mengetahui seberapa besar kontribusi konsep diri atas capaian belajar peserta didik kelas lima SD di sekolah tersebut.

4) Secara bersama-sama, untuk mengetahui seberapa besar kontribusi sikap sosial, status sosial ekonomi, dan konsep diri atas capaian belajar peserta didik kelas lima SD di sekolah tersebut.

\section{METODE}

Pendekatan dalam penelitian ini berupa "ex-post facto" sebab variabel penelitiannya tidak diperlakukan secara manipulasi atau teratment.

Populasi yang digunakan ialah seluruh murid Kelas V SD di gugus III Kecamatan Kerambitan Tabanan Tahun Ajaran 2020/2021 sebanyak 87 orang. Sementara sampel yang digunakan 
adalah semua dari jumlah populasi tersebut karena populasi yang diambil tidak terlalu banyak.

Variabel yang digunakan ada duam yaitu variabel terikat variabel bebas. Variabel bebasnya (X) yaitu sikap sosial (X1), status sosial ekonomi (X2), dan konsep diri (X3). Sementara variabel terikatnya $(Y)$ yaitu hasil belajar siswa.

Secara operasional, sikap sosial pada penelitian ini merupakan skor yang didapatkan oleh siswa setelah mengisi kuesioner sikap sosial berdasarkan skala likert 1-5. Dengan demikian data yang terkumpul bersifat interval. Adapun indikator yang digunakan untuk mengukur sikap sosial siswa adalah indikator menurut Devito (1997) yakni: 1), kerjasama 2) komunikasi, 3) empati, dan 4) keterbukaan.

Secara operasional, status sosial ekonomi pada penelitian ini merupakan skor yang didapatkan oleh siswa setelah mengisi kuesioner status sosial ekonomi berdasarkan skala likert 1-5. Sehingga data yang terkumpul bersifat interval. Adapun indikator sebagai alat ukur yaitu status sosial ekonomi siswa adalah indikator yang dikemukakan oleh Munandir (1996:10) yakni: jabatan, fasilitas berharga, kekayaan, penghasilan, pekerjaan dan pendidikan.

Secara operasional, konsep diri pada penelitian ini merupakan skor yang didapatkan oleh siswa setelah mengisi kuesioner konsep diri berdasarkan skala likert 1-5. Dengan demikian data yang terkumpul bersifat interval. Adapun indikator sebagai alat ukur yaitu gabungan dari para ahli yakni: 1) kondisi fisik siswa; 2) kondisi emosional siswa; 3) kepercayaan diri siswa; dan 4) hubungan sosial siswa dengan antar teman, guru dan orang lain.

Secara operasional, capaian belajar pada penelitian ini berupa nilai yang didapatkan siswa pada ulangan tengah semester di sekolah.

Metode pengumpulan datanya berdasarkan metode kuesioner, yaitu: 1) kuesioner sikap sosial, 2) kuesioner status sosial ekonomi, 3) kuesioner konsep diri. Sedangkan untuk capaian belajar peserta didik siswa menggunakan nilai ulangan tengah semester siswa yang ada di sekolah, sehingga pada penelitian ini tidak membuat instrument hasil belajar lagi.

Analisa datanya dibagi menjadi tiga tahap, yaitu: 1) Mendeskripsikan data, 2) Menguji syarat analisa, 3) Melakukan uji hopotesis.

Data yang didapatkan selanjutnya dijelaskan berdasarkan varibelveriabelnya. Adapun variabel-variabel tersebut antara lain sikap sosial, status sosial ekonomi, konsep diri dan hasil belajar. Pendeskripsian data berdasarkan dengan nilai rerata $(\mathrm{M})$, median $(\mathrm{Me})$, modus (Mo), dan standar deviasi (SD). Kemudian dihitung rerata skor ideal seluruh subjek dibagi dengan rerata kenyataan untuk mencari kecenderungannya.

Teknik analisis data berdasarkan teknik hubungan parallel, regresi ganda dan sederhana. Untuk pengujiam persyaratannya dilakukan dengan uji normalitas, linieritas, inieritas dan keberartian koefisien regresi, multikolonieritas, heterokedastisitas, dan autokorelasi.

\section{HASIL DAN PEMBAHASAN}

Merujuk pada uji kesimpulan awal atau hipotesis, diperoleh bebrapa hasil sebagai berikut.

1) Adanya kesignifikansi kontribusi antara hasil belajar siswa kelas V SD di gugus III Kecamatan Kerambitan Tabanan dengan sikap sosial.

Pengujian hipotesis pertama mendapatkan garis regresi $\hat{y}=36,196+$ $0,415 X 1$ dengan Freg $=117,101$ dan $r_{\text {hitung }}$ $=0,761$ signifikan pada $\alpha=0,05\left(r_{\text {tabel }}=\right.$ 0,213 ). Ini mengindikasikan bahwa adanya kontribusi yang signifikan sikap sosial terhadap hasil belajar siswa kelas V SD di gugus III Kecamatan Kerambitan Tabanan. Kontribusi sikap sosial atas capaian belajar murid kelas V SD di gugus III Kecamatan Kerambitan Tabanan sebesar $57,9 \%$.

Penelitian ini sejalan dengan penelitiannya Sagita (2014) yang berjudul Kontribusi Sikap Sosial dan Minat Belajar Terhadap Hasil Belajar PKn Siswa SMP Kelas VIII SMP Negeri 1 Melaya, Kecamatan Melaya Kabupaten Jembrana 
Tahun Pelajaran 2013/2014. Hasilnya memperlihatkan: (1) Adanya kesignifikansi kontribusi antara hasil belajar siswa dan sikap sosial (2) Adanya kesignifikansi kontribusi antara hasil belajar siswa dan minat belajar ekonomi, dan (3) Gabungan dari kedua variabel tersebut, Adanya kesignifikansi kontribusi antara hasil belajar siswa dengan sikap sosial dan minat belajar

Sikap sosial merupakan rasa sadar seseorang akan kondisi sekelilingnya sehingga menampakkan tindakan-tidakan nyata dan kemungkinan untuk bertindak di dalam keterlibatannya dengan masyarakat. Ciri seseorang memiliki sikap sosial yang baik adalah: 1) memiliki sikap keterbukaan yang baik, 2) memiliki sikap empati yang baik, 3) bisa berinteraksi dengan baik, dan 4) bisa bekerjasama dengan baik.

Devito (1997) mengatakan perilaku dengan menceritakan informasi diri kepada orang lain yang bersifat rahasia di namakan dengan keterbukaan diri. Keterbukaan siswa di dalam belajar dapat memudahkan pengajar untuk mengidentifikasi permasalahan/kendalakendala yang dihadapi siswa dalam belajar, sehingga guru akan dengan mudah mencarikan solusi untuk mengatasi permasalahan/kendala yang dihadapi siswa tersebut dan hasil belajar siswa pun dapat maksimal.

Batson (dalam Sarwono, 2009: 128) menjelaskan bahwa perilaku empati dan membantu orang lain akan menimbulkan rasa senang terhadap orang yang ditolong. Siswa yang mampu menguasai materi dengan baik, apabila melihat teman yang belum mengerti materi tersebut, maka siswa yang sudah mengerti dapat langsung mengajari siswa yang belum mengerti tersebut. Sehingga kegiatan tutor sebaya dalam pelaksanaan belajar bisa terlaksanan dengan efektif danprestasi siswa dapat ditingkatkan.

Selanjutnya, kemampuan berkomunikasi siswa dalam proses pembelajaran sangatlah penting. Mengingat pembelajaran hendaknya ada interaksi murid dengan murid, murid dengan guru atau murid dengan lingkungan sekitar. Untuk mewujudkan hal ini tentunya harus ada komunikasi yang aktif dan baik dari siswa. Terakhir yakni kerjasama yang baik, kerjasama adalah kunci kesuksesan dalam pelaksanaan pembelajaran. Dalam pembelajaran peserta didik harus berkerjasama untuk menyelesaikan suatu persoalan atau tugas-tugas sekolah sehingga peserta didik bisa lebih semangat dan aktif di dalam mengikuti pembelajaran.

Terkait dengan penjelasan tersebut bahwa bisa diambil kesimpulan sikap sosial berkontribusi secara signifikan atas hasil belajar murid Kelas V SD di gugus III Kecamatan Kerambitan Tabanan.

2) Adanya kesignifikansi kontribusi antara hasil belajar Siswa Kelas V SD di Gugus III Kecamatan Kerambitan Tabanan dengan status sosial ekonomi.

Pengujian hipotesis kedua mendapatkan garis regresi $\hat{y}=56,110+$ $0,234 X 2$ dengan Freg $=78,408$ dan $r_{\text {hitung }}$ $=0,693$ signifikan pada $\alpha=0,05\left(r_{\text {tabel }}=\right.$ 0,213). Ini mengindikasikan bahwa terdapat kontribusi yang signifikan status sosial ekonomi atas capaian belajar murid kelas V SD di gugus III Kecamatan Kerambitan Tabanan. Kontribusi status sosial ekonomi atas capaian belajar murid kelas V SD di gugus III Kecamatan Kerambitan Tabanan sebesar $48 \%$.

Penelitian ini sesuai dengan penelitiannya Khotimah dkk (2017) yang berjudul Pengaruh Status Sosial Ekonomi Orang Tua Terhadap Prestasi Belajar Siswa. Hasil penelitian menunjukkan bahwa terdapat kesignifikansi antara capaian belajar murid kelas VIII SMP negeri 1 Jember tahun ajaran 2016/2017) dengan status sosial ekonomi yang bisa diperhatikan pada nilai Fhitung $=268,491$ $>$ Ftabel $=3,112$ dengan tingkat signifikansi $F=0,000<a=0,05$. Persentase yang didpatakn pada stsatus ekonomi keluarga ialah $77,3 \%$, sementara $22,7 \%$ adalah faktor lainnya.

Selanjutnya penelitiannya Mukhlis, dkk (2020) yang berjudul Pengaruh Status Sosial Ekonomi Orang Tua Dan Motivasi Belajar Terhadap Prestasi Belajar Kimia Siswa SMA Negeri Di Kabupaten Konawe. Hasil penelitian menunjukkan bahwa: (1) 
persentase dari hasil belajar kimia akibat pengaruh dari status ekonomi keluarga sebesar 18\%; (2) persentase dari hasil belajar kimia akibat pengaruh dari motivasi belajar sebesar 29\%; (3) adanya dorongan belajar yang berbeda pada siswa di DAS dengan siswa di pesisir, (4) adanya pencapain hasil belajar yang berbeda pada siswa di DAS dengan siswa di pesisir. Terkait dengan penelitian ini dperoleh hasil atau kesimpulan bahwa motivasi belajar dan status ekonomi keluarga berpengaruh atas capaian belajar kimia SMA di Kabupaten Konawe.

Status sosial ekonomi suatu keluarga merupakan hal sangat penting dalam menunjang pendidikan anaknya di sekolah. Status sosial ekonomi orang bisa diperhatikan pada: oendidikan, pekerjaan, penghasilan, kepemilikan barang berharga orang tua, dan jabatan sosial masyarakat orang tua.

Pendidikan orang tua cenderung memberikan pengaruh kepada kepada anaknya untuk belajar. Orang tua yang berpendidikan cenderung memiliki keinginan untuk menyekolahkan atau memberikan pendidikan yang terbaik kepada anaknya. Hal ini akan membuat orang tua memberikan perhatian lebih kepada siswa untuk rajin belajar dan memdapatkan hasil belajar yang kebih baik. Seperti yang dikatakan Reskia, dkk (2014) yang menyatakan bahwa tingkat pendidikan bahwa salah satu yang mendorong siswa untuk belajar dan mendapatkan nilai lebih baik adalah tingkat pendidikan orang tuanya. Orang tua yang memiliki pendidikan lebiah baik tentunya bisa mendidik dan mengajar anaknya untuk terus berprestasi di sekolah dengan cara membantu anaknya mengerjakan tugas dan mengajarkan apa yang elum dipahami oleh anaknya di sekolah.

Orang tua yang sudah memiliki pekerjaan yang mapan tentunya mendapatkan penghasilan yang cukup bagi keluarga. Penghasilan yang cukup ini tentunya akan diiringi dengan kekayaan/kepemilikan barang berharga dari orang tua. Apabila penghasilan dan kekayaan sudah mencukupi tentunya fokus orang tua adalah pengembangan pendidikan anaknya. Maka dari itu, orang tua semenjak dini pasti memberikan pendidikan yang paling baik terhadap anak mereka dan selalu mendorong anaknya untuk berprestasi di sekolah, dan hasil belajar anaknya pun dapat ditingkatkan.

Selanjutnya jabatan sosial masyarakat orang tua. Orang tua yang mempunyai strata sosial masyarakat yang tinggi tentunya akan selalu mensuport pembelajaran anaknya di sekolah. Tidak bisa dipungkiri orang tua yang memiliki jabatan sosial masyarakat pasti merasa malu apabila anaknya tidak bersekolah atau kurang dalam pembelajaran yang diberikan di sekolah. Maka dari itu, orang tua akan berusaha membantu peningkatan hasil belajar anaknya di sekolah agar bisa optimal.

Berdasarkan pemaparan tersebut, bisa diambil kesimpulan bahwa status sosial ekonomi keluarga sangat mempengaruhi pendidikan peserta didik di sekolah. Peserta didik yang memiliki keluarga dengan status sosial ekonomi yang tinggi, cenderung mendapatkan fasilitas yang lengkap dalam belajar. Selain itu, biasanya siswa mengikuti berbagai bimbingan belajar di luar sekolah, sehingga mampu mendongkrak pencapaian belajar siswa di sekolah.

3) Adanya kesignifikansi kontribusi antara hasil belajar Siswa Kelas V SD di Gugus III Kecamatan Kerambitan Tabanan dengan konsep diri

Pengujian hipotesis ketiga mendapatkan garis regresi $\hat{y}=61,219+$ 0,264 X3 dengan Freg $=70,431$ dan $r_{\text {hitung }}$ $=0,673$ signifikan pada $\alpha=0,05\left(r_{\text {tabel }}=\right.$ 0,213). Ini mengindikasikan bahwa terdapat kontribusi yang signifikan konsep diri atas capaian belajar murid kelas V SD di gugus III Kecamatan Kerambitan Tabanan. Kontribusi konsep diri atas capaian belajar murid kelas V SD di gugus III Kecamatan Kerambitan Tabanan sebesar $45,3 \%$.

Penelitian ini sejalan dengan penelitiannya Saputra dan Nelda (2019) yang berjudul Kontribusi Konsep Diri Dan Pemanfaatan Fasilitas Praktikum Terhadap Hasil Belajar Dasar Listrik 
Elektronika. Hasilnya memperlihatkan: (1) persentase kontribusi dari pemanfaatan fasilitas praktikum dengan konsep diri atas capaian belajar peserta didik sebesar 47,88\%; (2) persentase kontribusi konsep diri atas capaian belajar peserta didik sebesar 21,34\%; (3) persentase kontribusi pemanfaatan fasilitas praktikum atas capaian belajar sebesar 31,47\%. Kesimpulan yang didapatkan adalah capaian belajar di SMK Negeri 5 Padang dipengaruhi oleh pemanfaatan fasilitas praktikum dan konsep diri.

Selanjutnya penelitian yang dilakukan oleh Hanifah dan Agung (2019) dengan judul Hubungan Antara Konsep Diri Dengan Prestasi Akademik Mahasiswa Pada Mata Kuliah Teori Grup. Hasil analisanya didapatkan nilai hubungan koefisien dari prestasi belajar dengan dan konsep diri sebesar 0,41. Terkait dengan data yang didapatkan tersebutm disimpulkan bahwa prestasi belajar dengan konsep diri memiliki korelasi yang baik dan signifikan.

Konsep diri merupakan kemampuan seseorang dalam memahami dirinya sendiri sehingga mampu mengkondisikan dirinya pada situasi yang dihadapinya. Ciri siswa memiliki konsep diri yang baik dapat dilihat dari: 1) kondisi fisik siswa; 2) kondisi emosional siswa; 3) kepercayaan diri siswa; dan 4) hubungan sosial siswa dengan antar teman, guru dan orang lain.

Siswa yang memiliki kondisi fisik yang baik tentunya lebih mampu berpikir yang positif terhadap dirinya. Dengan pikiran positif ini, tentunya akan mampu membuat siswa belajar lebih fokus di sekolah. Selanjutnya kondisi emosional siswa. Tidak dapat dipungkiri kondisi emosial siswa termasuk sesuatu yang berpengaruh do dalam belajar. Dalam proses pembelajaran diperlukan ketenangan dan kemampuan siswa dalam mengelola emosinya. Hal ini dikarenakan dalam pembelajaran siswa pasti akan menemukan kendala atau permasalahanpermasalahan yang harus dihadapinya. Untuk mengatasi kendala dan permasalahan dalam pembelajaran tersebut tentunya diperlukan kondisi emosional posistif dalam diri peserta didik. Seperti halnya pendapat Menurut Ernawati dan Yustina (2017) menyatakan bahwa kondisi fisik siswa mempengaruhi motivasi belajar siswa di sekolah. Semakin baik kondisi fisik siswa di sekolah, maka motivasi belajar yang ditunjukkan oleh siswa pun semakin baik, dan hasil belajar siswa pun dapat ditingkatkan.

Selanjutnya dalam pembelajaran tentunya juga diperlukan kepercayaan diri siswa dalam melakukan sesuatu atau berargumentasi dalam kegiatan pembelajaran. Peserta didik dengan optimistis kepercayaan diri positif, tentunya akan lebih berani dalam mengembangkan pengetahuan atau pembelajaran di kelas. Seperti pendapatnya pendapat yang dinyatakan oleh Adriani (2018) yaitu capaian belajar dengan percaya diri siswa mempunyai pengaruh yang positif dan signifikan.

Terakhir adalah hubungan sosial siswa dengan antar teman, guru dan orang lain. Hubungan sosial siswa dengan antar teman, guru dan orang lain sangatlah penting dalam proses pembelajaran. Siswa yang memiliki inetraksi yang baik dengan lingkungannya, tentunya akan lebih berani berdiskusi ataupun meminta bantuan apabila dirinya mengalami permasalahan atau kendala dalam proses pembelajaran. Seperti yang dikatakan Rahmawati dan Dian (2014) yaitu ada hubungan interaksi sosial dengan capaian belajar. Semakin baik interaksi sosial, akan terus membaik capaian hasil belajarnya di sekolah.

Uraian di atas mengindikasikan konsep diri siswa memiliki pengaruh yang penting untuk meningkatkan kualitas belajar siswa di sekolah. Dengan konsep diri yang tinggu menjadikan hasil belajar siswa cenderung maksimal. Terkait dengan penjelasan tersebut maka diduga konsep diri memiliki pengaruh positif dan signifikan ata hasil belajar siswa Kelas V SD di gugus III Kecamatan Kerambitan Tabanan.

4) Secara bersama-sama, adanya kesignifikansi kontribusi antara hasil belajar Siswa Kelas V SD di Gugus III Kecamatan Kerambitan Tabanan dengan sikap sosial, status sosial ekonomi, dan konsep diri. 
Pengujian hipotesis keempat mendapatkan garis regresi $\hat{y}=33,193+$ $0,260 \times 1+0,073 \times 2+0,131 \times 3$ dengan Freg $=78,031$ dan $R_{\text {hitung }}=0,859$ signifikan pada $\alpha=0,05\left(r_{\text {tabel }}=0,213\right)$. Ini mengindikasikan bahwa terdapat secara bersama-sama, terdapat kontribusi yang signifikan sikap sosial, status sosial ekonomi, dan konsep diri terhadap hasil belajar siswa kelas V SD di gugus III Kecamatan Kerambitan Tabanan. Kontribusi sikap sosial, status sosial ekonomi, dan konsep diri terhadap hasil belajar siswa kelas V SD di gugus III Kecamatan Kerambitan Tabanan sebesar $73,8 \%$.

Pencapaian belajar adalah kemampun yang didapatkan melalui kegiatan belajar. Salah satu indikator bahwa pembelajaran sudah tercapai secara optimal adalah tercapainya hasil belajar sesuai dengan tujuan dan yang diharapkan.

Dalam belajar, tentunya dipengaruhi oleh berbagai faktor baik internal maupun eksternal. Faktor internal yang mempengaruhi hasil belajar adalah sikap sosial dan konsep diri yang dimiliki siswa. Sedangkan faktor eksternal yang mempengaruhi hasil belajar adalah status sosial ekonomi keluarga siswa.

Semakin baik sikap sosial, konsep diri dan status sosial ekonomi yang dimiliki siswa, maka hasil belajar siswa di sekolah cenderung baik pula. Hal ini dikarenakan siswa sudah memiliki kemampuan untuk mengendalikan diri dan mengetahui potensi dirinya sehingga mampu memilih dan memilah kegiatan yang positif terhadap peningkatan hasil belajarnya. Apalagi ditambah dengan diberikannya fasilitas yang memadai dari keluarga, tentunya akan dapat memotivasi siswa dalam belajar.

Terkait dengan penjelasan tersebut kesimpulan yang didpatakan ialah adanya signifikansi antara capaian belajar siswa Kelas V SD di gugus III Kecamatan Kerambitan Tabanan dengan sikap sosial, status sosial ekonomi, dan konsep diri.

Berdasarkan penelitian di gugus III Kecamatan Kerambitan Tabanan terlihat beberapa implikasi yang muncul di lapangan. Adapun implikasinya tersebut adalah sebagai berikut.

1. Penelitian ini memberikan implikasi kepada guru. Dengan adanya penelitian ini guru menjadi tahu dan mendapatkan informasi yang akurat tentang pentingnya menumbuhkan sikap sosial siswa dan konsep diri siswa dalam proses pembelajaran. Hal itu dikarenakan pada penelitian ini sudah terbukti bahwa sikap sosial dan konsep diri siswa berpengaruh atas capaian belajar peserta didik

2. Penelitian ini memberikan implikasi kepada siswa. Dengan adanya penelitian ini siswa menjadi lebih termotivasi dalam menjalin pergaulan yang harmonis dan menjunjung konsep diri yang telah dimilikinya.

3. Penelitian ini memberikan implikasi kepada orang tua siswa. Melalui research ini, orang tua siswa menjadi memahami betapa pentingnya status sosial ekonomi atas capaian belajar anaknya, sehingga orang tua akan selalu berusaha lebih baik lagi demi cita-cita anaknya.

\section{PENUTUP}

Adapun kesimpulan yang didapatkan dalam penelitian di gugus III Kecamatan Kerambitan Tabanan adalah sebagai berikut.

1) Adanya kesignifikansi kontribusi antara hasil belajar siswa dan sikap sosial sebesar $57,9 \%$ dan kefektifan sambungan sebesar $36,29 \%$,

2) Adanya kesignifikansi kontribusi antara hasil belajar siswa dan status sosial ekonomi sebesar $48 \%$ dan kefektifan sambungan sebesar $14,99 \%$,

3) Adanya kesignifikansi kontribusi antara hasil belajar siswa dan konsep diri sebesar 45,3\% dan kefektifan sambungan sebesar $22,50 \%$,

4) Gabungan dari ketiga variabel tersebut, Adanya kesignifikansi kontribusi antara hasil belajar siswa dengan sikap sosial, status sosial ekonomi, dan konsep diri sebesar $73,8 \%$. 
Terkait dengan penelitian yang telah dilakukan, adapun hal-hal yang bisa disarankan pada penelitian ini antara lain

1) Siswa hendaknya selalu berusaha meningkatkan sikap sosial dan konsep diri yang dimilikinya, sehingga memperoleh prestasi belajar yang lebik baik.

2) Guru hendaknya selalu memperhatikan faktor-faktor yang mempengaruhi hasil belajar siswa, sehingga tujuan dan harapan belajar bisa diperoleh secara maksimal.

3) Orang tua hendaknya selalu memberikan dukungan penuh terhadap pendidikan anaknya, sehingga anaknya mampu berkontribusi bagi kemajuan bangsa dan negara.

4) Peneliti lain, apabila melakukan penelitian dengan tema yang mirip maka penelitian ini bida digunakan untuk salah satu pedoman dalam melaksanakan penelitiannya.

\section{DAFTAR RUJUKAN}

Adriani, Deni. 2018. Pengaruh Percaya Diri, Kebiasaan Belajar dan Motivasi Belajar Terhadap Hasil Belajar Siswa Pada Mata Pelajaran Ekonomi. Jurnal Pendidikan Ekonomi, Manajemen Dan Keuangan Vol. 2 No. 1 Mei 2018 Hal. $19-28$.

Chotimah, dkk. 2017. Pengaruh Status Sosial Ekonomi Orang Tua Terhadap Prestasi Belajar Siswa. Jurnal IImiah IImu Pendidikan, IImu Ekonomi, dan IImu Sosial Volume 11 Nomor 2.

Devito, Joseph A. 1997. Human Communication. Alih Bahasa Agus Maulana dkk, Komunikasi Antar Manusia. Jakarta: Profesional Book.

Dimyati \& Mudjiono. 2013. Belajar dan Pembelajaran. Jakarta: PT.Rineka Cipta.

Dimyati, Mahmud. 1990. Psikologi Pendidikan. Jakarta: Depdikbud.
Ernawati, Lia dan Yustina Sri Aminah. 2016. Pengaruh Kondisi Fisik Siswa Dan Lingkungan Sekolah Terhadap Motivasi Belajar Bidang Studi Ekonomi Siswa Kelas X MA NU Ibtidaul Falah Kudus Tahun Ajaran 2015/2016. Economic Education Analysis Journal Nomor 6 Volume 1 tahun 2017.

Hanifah dan Agung Prasetyo Abadi. 2019. Hubungan Antara Konsep Diri Dengan Prestasi Akademik Mahasiswa Pada Mata Kuliah Teori Grup. Jurnal Matematika KreatifInovatif Volume 10 Nomor 2 Halaman 141-145.

Mukhlis, dkk. 2020. Pengaruh Status Sosial Ekonomi Orang Tua Dan Motivasi Belajar Terhadap Prestasi Belajar Kimia Siswa SMA Negeri Di Kabupaten Konawe. Jurnal Penelitian Pendidikan Fisika Volume 5 Nomor 1.

Munandir. 1996. Program Bimbingan Karir di Sekolah. Jakarta. Departemen Pendidikan dan Kebudayaan.

Nasution. 1994. Berbagai Pendekatan Belajar dan Mengajar. Jakarta: Bina Aksara.

Rahmawati dan Dian. 2014. Hubungan Interaksi Sosial Dengan Hasil Prestasi Belajar Mahasiswa Semester IV Program Studi Diploma III Kebidanan Unipdu Jombang. Jurnal Edu Health, Vol. 4 No. 2, September 2014.

Sagita, Putu Yeni. 2014. Kontribusi Sikap Sosial dan Minat Belajar Terhadap Hasil Belajar PKn Siswa SMP Kelas VIII SMP Negeri 1 Melaya, Kecamatan Melaya Kabupaten Jembrana Tahun Pelajaran 2013/2014. Jurnal Pendidikan Kewarganegaraan Undiksha Volume 4 Nomor 3.

Saputra, Nanda dan Nelda Azhar. 2019. Kontribusi Konsep Diri Dan 
Pemanfaatan Fasilitas Praktikum Terhadap Hasil Belajar Dasar Listrik Elektronika. Jurnal Vokasional Teknik Elektronika danInformatika Volume 7 Nomor 2.

Sarwono, S.W dan Eko A.M. 2009.

Psikologi Sosial. Jakarta: Salemba Humanika

Uno, H. 2011. Teori Motivasi dan Pengukurannya. Jakarta: PT Bumi. Aksara

Usman Sunyoto. 2004. Pembangunan dan Pemberdayaan Masyarakat. Yogyakarta: Pustaka Pelajar. 